\title{
Effectiveness of green betel leaf and lime extract against Staphylococcus aureus and Escherichia coli
}

\author{
RIA YULIA GLORIA ${ }^{1, \bullet}$, RAHMA YULIYANI ${ }^{2}$, MIA MAR'ATUSH SHOLIHA ASROR ${ }^{3}$ \\ ${ }^{1}$ Department of Biology Education, Faculty of Teacher Training and Educational Sciences, IAIN Syekh Nurjati. Jl. Perjuangan Sunyaragi, Cirebon \\ 45132, West Java, Indonesia. Tel.: +62-231-481264, •email: riyulgloria@gmail.com \\ ${ }^{2}$ Graduate Program, Universitas Negeri Semarang. Jl Kelud Utara III, Semarang 50237, Central Java, Indonesia \\ ${ }^{3}$ Science Laboratory, Faculty of Teacher Training and Educational Sciences, IAIN Syekh Nurjati. Jl. Perjuangan Sunyaragi, Cirebon 45132, West Java, \\ Indonesia
}

Manuscript received: 10 March 2021. Revision accepted: 26 July 2021.

\begin{abstract}
Gloria RY, Yuliyani R, Asror MMS. 2021. Effectiveness of green betel leaf and lime extract against Staphylococcus aureus and Escherichia coli. Biodiversitas 22: 3452-3457. Indonesian society utilizes biodiversity as source of medicinal herbs. Betel leaf and lime are included in traditional Indonesian medicinal plants that have antibacterial and antioxidant properties. One of the benefits of herbal medicinal plants of betel leaf and lime is that it can be used as a natural hand sanitizer. The purpose of this study was to test the effectiveness of naturally made hand sanitizer against Staphylococcus aureus and Escherichia coli by the combination of green betel leaf extract and lime extract. The experiment was performed by the Kirby-Bauer disc diffusion method. Results showed that a combination of $50 \%$ betel leaf extract and 50\% lime extract inhibited the growth of S. aureus whereas, $75 \%$ betel leaf extract and $100 \%$ lime extract exhibited strong inhibition than $70 \%$ alcohol.
\end{abstract}

Keywords: Citrus aurantifolia, Escherichia coli, green betel leaf, hand sanitizer, Piper betle, Staphylococcus aureus

\section{INTRODUCTION}

The biodiversity of medicinal plants in Indonesia is very diverse and abundant. The commonly used medicinal plants in the public are betel and lime. Several studies on the benefits of leaves of betel and lime have a lot to do. The results of the study showed many benefits positives were found in the leaves of the betel and lime. The effective part of the betel plant is leaves, while the lime plant is fruit.

In the betel plant, leaves are mostly used because they contain many phenol derivative compounds. The maceration and reflux methods showed that betel leaf extract contained antibacterial compounds that were effective in inhibiting Staphylococcus aureus (Bustanussalam et al. 2015). Several studies have reported that ethyl acetate leaf extract showed antibacterial activity against S. epidermidis (Kursia et al. 2016).

Apart from betel leaf, lime is also a traditional Indonesian medicinal plant that has antibacterial and antioxidant properties. Lime is rich in citric acid, its extract contains 7-8\% of citric acid (Sarwono 2001). Due to the presence of flavonoids in lime, it showed antifungal, antioxidant, anticancer, antibacterial, and anti-cholesterol activities. It is also used as a tooth whitener and mosquito larvicide (Prastiwi and Ferry 2017).

Lauma et al (2015) reported that $100 \%$ concentration of lime extract can inhibit the growth of $S$. aureus. Puspita and Hairunnisa (2020) observed that the inhibition zone of
S. aureus by lime extract treatment was $100 \%$ significantly different from other treatments. The inhibition zone at $100 \%$ concentration was greater than the inhibition zone at $25 \%, 50 \%$, and $75 \%$ concentrations.

Based on earlier studies about the benefits of betel and lime, both plants have medicinal properties that can be used as hand sanitizers. Hand sanitizer helps to remove pathogens on the skin surface. Hand sanitizer can generally be categorized into two groups: alcohol-based (ABHS) or alcohol-free. ABHS can effectively and quickly reduce microbes and cover a broad germicidal spectrum without the need for water or towels. On the other hand, alcoholfree sanitizers are made up of natural compounds that have antiseptic properties and antimicrobial effects (Jinget al. 2020).

Based on the above description and remembering the importance of hand sanitizer during a pandemic, it is necessary to find an alternative compound to be used in alcohol-free hand sanitizer which is easily obtained and natural. Natural hand sanitizers can be easily made by the people of Indonesia using betel and lime. Several studies have proven that both types of medicinal plants have antibacterial properties, so their extracts can eliminate pathogens on the skin surface. The purpose of this study was to test the effectiveness of hand sanitizer spray made from a mixture of green betel leaf extract and lime extract against Staphylococcus aureus and Escherichia coli bacteria. 


\section{MATERIALS AND METHODS}

\section{Study area}

The study was conducted on January $18^{\text {th }}-23^{\text {rd }}, 2021$ at the Laboratory of Science and Mathematics IAIN Syekh Nurjati Cirebon, by using the Kirby Bauer method.

\section{Instruments and materials}

The instruments used in the present study were hot air oven, autoclave, analytical balance, incubator, and hot plates with magnetic stirrer bar. Whereas test tubes, Petri dishes, ose needles, cotton plug, Erlenmeyer flask, glass stirring rod, tweezer sandpaper discs were used to carry out the experiment. The main ingredients used for hand sanitizer were lime fruit extract, betel leaf extract, distilled water, and $70 \%$ alcohol as control treatment. The aqueous betel leaf extract was made by maceration method and lime extract was obtained from the pulp. Three types of media were used for bacterial growth, such as Mannitol Salt Agar (MSA), Mac Conkey Agar (MCA), and Nutrient Agar (NA).

\section{Purificationofbacteria}

To obtain a pure culture $S$. aureus and E. coli, three steps were performed, such as isolation, inoculation, and purification. S. aureus bacteria were isolated from the skin surface using sterile cotton buds. Then samples were inoculated to MSA media in a zigzag pattern and incubated for $1 \times 24$ hours in an incubator at $37^{\circ} \mathrm{C}$. After 24 hours, Staphylococcus aureus bacteria were transferred to new MSA media and incubate for 24 hours at $37^{\circ} \mathrm{C}$. After inoculation on new MSA media, the final process was purifying bacteria. The bacteria were purified by transferring the inoculum onto oblique (slant) NA medium and incubate at $37^{\circ} \mathrm{C}$ for $1 \times 24$ hours. The final step to make a pure bacterial culture is to add $5 \mathrm{ml}$ of distilled water to each test tube. The same process was performed in making a pure culture of $E$. coli. The difference was in the source from where the bacteria was isolated and the medium in which it was grown. The E. coli was isolated from toilet water using sterile cotton buds, then inoculated on MCA media (Mac Conkey Agar). Further processing was similar to the procedure carried out in S. aureus culture.

\section{Preparation of hand sanitizer}

Hand sanitizer was made from a mixture of betel leaf extract, lime extract (citrus), and distilled water. The extract of betel leaf was obtained by the maceration method by mixing 75 grams of betel leaves in $100 \mathrm{ml}$ of water (for 75\% concentration). Further 50\% and 25\% concentrations were made by dilution method.

The lime extract was obtained by squeezing the lime fruit. A $100 \%$ concentration was obtained without mixing the distilled water into the extract while $75 \%$ and $50 \%$ concentrations were made by diluting the extract with distilled water. The hand sanitizer was made by mixing betel leaf extract and lime extract and distilled water at different concentrations.

\section{The Kirby Bauer Method}

The effectiveness of hand sanitizer was investigated using the Kirby Bauer method (disc-diffusion). Nutrient agar media was prepared and poured into a petri dish. Then $0.1 \mathrm{ml}$ of pure bacterial culture was inoculated into a petri dish and evenly spread using a spreader rod. Subsequently, the paper discs were soaked in hand sanitizers of different concentrations and placed on the top surface of media with the help of tweezers and incubate for $1 \times 24$ hours at $37^{\circ} \mathrm{C}$. The treatment used in this study was as follows: (i) Treatment 1 (P1): Control (70\% Alcohol), (ii) Treatment 2 (P2): $25 \%$ Betel Leaf Extract and 50\% Lime Extract, (iii) Treatment 3 (P3): 25\% Betel Leaf Extract and 75\% Lime Extract, (iv) Treatment 4 (P4): 25\% Betel Leaf Extract and 100\% Lime Extract, (v) Treatment 5 (P5): 50\% Betel Leaf Extract and 50\% Lime Extract, (vi) Treatment 6 (P6): 50\% Betel Leaf Extract and 75\% Lime Extract, (vii) Treatment 7 (P7): 50\% Betel Leaf Extract and 100\% Lime Extract, (viii) Treatment 8 (P8): 75\% Betel Leaf Extract and 50\% Lime Extract, (ix) Treatment 9 (P9): 75\% Betel Leaf Extract and 75\% Lime Extract, (x) Treatment 10 (P10): 75\% Betel Leaf Extract and 100\% Lime Extract.

\section{Statistical analysis of the effectiveness of natural hand sanitizer}

The statistical method was performed to test the effectiveness of the hand sanitizer. This test was performed to compare the inhibitory ability of the combination of these two extracts compared to alcohol. Alcohol was used as a comparison because it was commonly used in hand sanitizer spray.

Two types of statistical tests were performed, namely prerequisite test and hypothesis test. The prerequisite test is also known as Shapiro-Wilk normality test and the amount of data should be less than 30 . If the data were normally distributed, then the statistical test can be continued with a hypothesis test in the form of a One-Sample T-Test with the test value used depending on the value of the inhibition of each alcohol treatment.

A group of data was said to be normally distributed if the significance value was more than 0.05 . Meanwhile, in hypothesis testing, there were two types of hypotheses, namely H1and H0. In decision-making criterion, if the resulting significance value was more than 0.05 , (sig.) 0.05 ) then the accepted hypothesis was H0. Meanwhile, if the resulting significance value was less than 0.05 (sig. $<0.05$ ), then the accepted hypothesis was $\mathrm{H} 1$.

The following explanation of the two types of hypotheses in this study was (i) $\mathrm{H} 0=$ The average inhibition power in the combination of green betel leaf extract and the lime extract was same as the inhibitory power produced by $70 \%$ alcohol, (ii) $\mathrm{H} 1=$ The average inhibition power in the combination of green betel leaf extract and the lime extract was not same as the inhibitory power produced by $70 \%$ alcohol. 


\section{RESULTS AND DISCUSSION}

\section{Inhibition of Staphylococcus aureus by the combination of betel extract and lime extract}

The results of this research are presented in Table 1 . The results revealed that higher concentrations of betel leaf extract and lime extract showed higher zone of inhibition. The lowest concentration of extracts did not show much fluctuation in the inhibition zone. The diameter of inhibition zone in the control treatment (P1) was similar to P4 treatment.

The result showed that the effectiveness of alcohol was equivalent to the effectiveness of the combination between $25 \%$ betel leaf extract and $100 \%$ lime extract. Treatments ranging from 5 to 10 were more effective against $S$. aureus than $70 \%$ alcohol (Table 1).

To compare the inhibitory power produced by the combination of betel leaf extract and lime extract with alcohol, a statistical test was carried out. The statistical test was performed using the size of inhibition area produced by alcohol and the first treatment (P1) as the basic standard. The statistical test performed was the OneSample T-Test. This test was carried out on S. aureus and E. coli bacteria.

Before the One-Sample T-Test, normality test was carried out first on the data to be tested. The data must be normally distributed before testing the One-Sample T-Test. Table 2 showed the normality test output on the second to ninth inhibitory power data against $S$. aureus.

The data tested in the normality test only amounted to 9 because of the data from the first treatment (P1) was used as the basic standard for testing the One-Sample T-Test. Thus, the significance value was determined in the Shapiro-Wilk Test. The Shapiro-Wilk significance value was 0.214 . It showed that the data was normally distributed because the data was more than 0.05. Because the prerequisite testing has been completed, the hypothesis was tested using a One-Sample T-Test.

Based on the results of the hypothesis testing based on a test value of 8.7 (Table 3), it is known that the resulting significance value was 0.106 . This value indicates that the inhibitory power shown by treatment 2 to treatment 10 accepted the hypothesis $\mathrm{H} 0$ because the significance value was greater than 0.05 .

\section{Inhibition of Escherichia coli by the combination of betel extract and lime extract}

The results exhibited that the lowest concentration (P2) of the combination showed clear (inhibition) zone. It was also observed that as the concentration of extracts increased, so did the area of inhibition (Table 4). In E. coli, inhibition zone was found to be equivalent in control and treatment P2. While the inhibition zone of control in $S$. aureus was equal to $\mathrm{P} 4$ treatment. The results indicate that the effectiveness of alcohol was equivalent to the effectiveness of $\mathrm{P} 2$ combination $(25 \%$ betel leaf extract and $50 \%$ lime extract). So, all (P2 to $\mathrm{P} 10)$ treatments were more effective against $E$. coli than $70 \%$ alcohol (Table 4$)$.

Differences in inhibition zones between $S$. aureus and $E$. coli may be strongly influenced by several factors, such as toxicity of the test organism, diffusion capacity of the extracts on the media, interactions between the components of the medium, and microenvironmental conditions.

Table 1. The diameter of inhibition zone in Staphylococcus aureus culture

\begin{tabular}{llc}
\hline $\begin{array}{c}\text { Treat- } \\
\text { ments }\end{array}$ & \multicolumn{1}{c}{ Description of treatments } & $\begin{array}{c}\text { Diameter } \\
(\mathbf{m m})\end{array}$ \\
\hline P 1 & Alcohol 70\% & 8.7 \\
P 2 & 25\% betel leaf extract and 50\% lime extract & 7.5 \\
P 3 & 25\% betel leaf extract and 75\% lime extract & 8 \\
P 4 & 25\% betel leaf extract and 100\% lime extract & 8.7 \\
P 5 & 50\% betel leaf extract and 50\% lime extract & 9 \\
P 6 & 50\% betel leaf extract and 75\% lime extract & 9.15 \\
P 7 & 50\% betel leaf extract and 100\% lime extract & 10.5 \\
P 8 & 75\% betel leaf extract and 50\% lime extract & 10.8 \\
P 9 & 75\% betel leaf extract and 75\% lime extract & 11.0 \\
P 10 & 75\% betel leaf extract and 100\% lime extract & 11.0 \\
\multicolumn{2}{c}{ Average } \\
\hline
\end{tabular}

Table 2. Normality test of inhibition zone against Staphylococcus aureus

\begin{tabular}{lccccccc}
\hline & \multicolumn{9}{c}{ Tests of normality } \\
\cline { 2 - 7 } & \multicolumn{4}{c}{ Kolmogorov-Smirnov $^{\text {a }}$} & \multicolumn{4}{c}{ Shapiro-Wilk } \\
\cline { 2 - 7 } & Statistic & Df & Sig. & Statistic & Df & Sig. \\
\hline Inhibition zone of $S$. aureus & .212 & 9 & $.200^{*}$ & .893 & 9 & .214 & 9 \\
\hline
\end{tabular}

Note: a. Lilliefors Significance Correction, *. This is a lower bound of the true significance

Table 3. Hypothesis test for inhibitory power against Staphylococcus aureus

\begin{tabular}{|c|c|c|c|c|c|c|}
\hline & \multicolumn{6}{|c|}{$\begin{array}{l}\text { One-sample test } \\
\text { Test value }=8.7\end{array}$} \\
\hline & \multirow[b]{2}{*}{$\mathbf{t}$} & \multirow{2}{*}{ Df } & \multirow{2}{*}{ Sig. (2-tailed) } & \multirow{2}{*}{ Mean difference } & \multicolumn{2}{|c|}{$95 \%$ Confidence interval of the difference } \\
\hline & & & & & Lower & Upper \\
\hline Inhibition zone of $S$. aureus & 1.823 & 8 & .106 & .81667 & -.2164 & 1.8497 \\
\hline
\end{tabular}


A pre-requisite test in the form of a normality test and a hypothesis test in the form of a One-Sample T-Test was carried out on the inhibitory power data against $E$. coli bacteria. The data used for the two types of tests amounted to 9 data, namely the power of the second treatment to the tenth treatment. Table 5 is the results of the normality test of the data which further tested with the One-Sample TTest.

The data tested in the normality test only amounted to 9. The Shapiro-Wilk significance value was 0.124 . This shows that the data was normally distributed because the data was more than 0.05 . Based on the results of hypothesis the test value was 7.7 and the significance value was 0.003 (Table 6). This suggests that two to ten treatments showed inhibitory potency, which was not shown by alcohol. In other words, it can be said that the most accepted hypothesis is $\mathrm{H} 0$ because the significance value is less than 0.05 .

In the Kirby Bauer test, it was found that the average value of inhibition by alcohol for $S$. aureus was $8.7 \mathrm{~mm}$. By looking at the average concentration of $S$. aureus, the ideal hand sanitizer concentration was starting from a mixture of $25 \%$ betel extract, $100 \%$ orange extract and the volume ratio of each with distilled water was 15: 8: 77 . Kirby Bauer test using E. coli produced inhibitory zone 7.7 $\mathrm{mm}$ in diameter $25 \%$ betel extract, $50 \%$ orange extract, and distilled water were found effective in inhibition of $E$. coli. The volume ratio of the three ingredients was 15: 8: 77 consisting of $15 \mathrm{ml}$ betel extract, $8 \mathrm{ml}$ orange extract, and $77 \mathrm{ml}$ distilled water. The results showed that the combination of betel leaf extract and lime extract had the same inhibitory power as alcohol against $S$. aureus bacteria and had an average inhibition power that was not the same as $E$. coli bacteria (Figure 1).

In both $S$. aureus and $E$. coli bacteria, the inhibition zone was similar in each treatment from the second treatment to the tenth treatment. The appearance of a clear zone indicates that certain antibacterial substances have inhibited the growth of a bacterial colony even though there was a difference in the width of the clear zone. There were several factors that cause differences in the effectiveness of natural hand sanitizers. The combination of betel leaves extract and lime extracts were able to inhibit the growth of $S$. aureus and E. coli. A concentration of $25 \%$ betel leaves extract and $100 \%$ lime extract was found effective on $S$. aureus. Whereas, $25 \%$ betel leaves extract and $50 \%$ lime extract was effective against E. coli. The higher concentration of betel leaves and lime extracts were more effective against the growth of $S$. aureus and E. coli bacteria.

\section{Discussion}

Leaves of Piper betle extract contain different levels of phytochemicals. Young leaves contain high levels of saponins while the old leaves contain moderate levels of saponins. $S$. aureus is a gram-positive bacterium that normally existed on the skin surface of the hand. This bacteria could enter the bloodstream, the infection can occur in several internal organs. According to (Tong et al. 2015), S. aureus bacteria can cause pneumonia and emphysema, gastroenteritis, meningitis, and infections of the urinary tract. The infection caused by $S$. aureus bacteria depends on the strain involved and the site of infection. These bacteria bind to the extracellular matrix protein and fibronectin in cases of infectiousendo carditis. The walls of cells of bacteria are associated with proteins such as fibrinogen are intermediary of infectiousendo carditis (DeLeo et al. 2010).

Table 4. Diameter of inhibition zone in Escherichia coli culture

\begin{tabular}{llc}
\hline $\begin{array}{c}\text { Treat- } \\
\text { ments }\end{array}$ & \multicolumn{1}{c}{ Description of Treatments } & $\begin{array}{c}\text { Diameter } \\
(\mathbf{m m})\end{array}$ \\
\hline P 1 & Alcohol 70\% & 7.7 \\
P 2 & 25\% betel leaf extract and 50\% lime extract & 7.8 \\
P 3 & 25\% betel leaf extract and 75\% lime extract & 8 \\
P 4 & 25\% betel leaf extract and 100\% lime extract & 8.5 \\
P 5 & 50\% betel leaf extract and 50\% lime extract & 8.8 \\
P 6 & 50\% betel leaf extract and 75\% lime extract & 9.2 \\
P 7 & 50\% betel leaf extract and 100\% lime extract & 10.6 \\
P 8 & 75\% betel leaf extract and 50\% lime extract & 10.8 \\
P 9 & 75\% betel leaf extract and 75\% lime extract & 11.0 \\
P 10 & 75\% betel leaf extract and 100\% lime extract & 11.1 \\
\multicolumn{2}{c}{ Average } \\
\hline
\end{tabular}

Table 5. Normality test of inhibition zone against Escherichia coli

\begin{tabular}{lccccccc}
\hline & \multicolumn{4}{c}{ Tests of normality } \\
\cline { 2 - 7 } & \multicolumn{4}{c}{ Kolmogorov-Smirnov $^{\text {a }}$} & \multicolumn{4}{c}{ Shapiro-Wilk } \\
\cline { 2 - 7 } & Statistic & Df & Sig. & Statistic & Df & Sig. \\
\hline Inhibition zone of $E$. coli & .231 & 9 & $.182^{*}$ & .870 & 9 & .124 \\
\hline
\end{tabular}

Note: a. Lilliefors Significance Correction, *. This is a lower bound of the true significance

Table 6. Hypothesis test results for inhibitory power against Escherichia coli

\begin{tabular}{|c|c|c|c|c|c|c|}
\hline & \multicolumn{6}{|c|}{$\begin{array}{l}\text { One-sample test } \\
\text { Test value = 7.7 } \\
\end{array}$} \\
\hline & \multirow[b]{2}{*}{$\mathbf{t}$} & \multirow{2}{*}{ Df } & \multirow{2}{*}{ Sig. (2-tailed) } & \multirow{2}{*}{ Mean difference } & \multicolumn{2}{|c|}{ 95\% Confidence interval of the difference } \\
\hline & & & & & Lower & Upper \\
\hline Inhibition zone of E. coli & 4.097 & 8 & .003 & 1.83333 & .8013 & 2.8653 \\
\hline
\end{tabular}




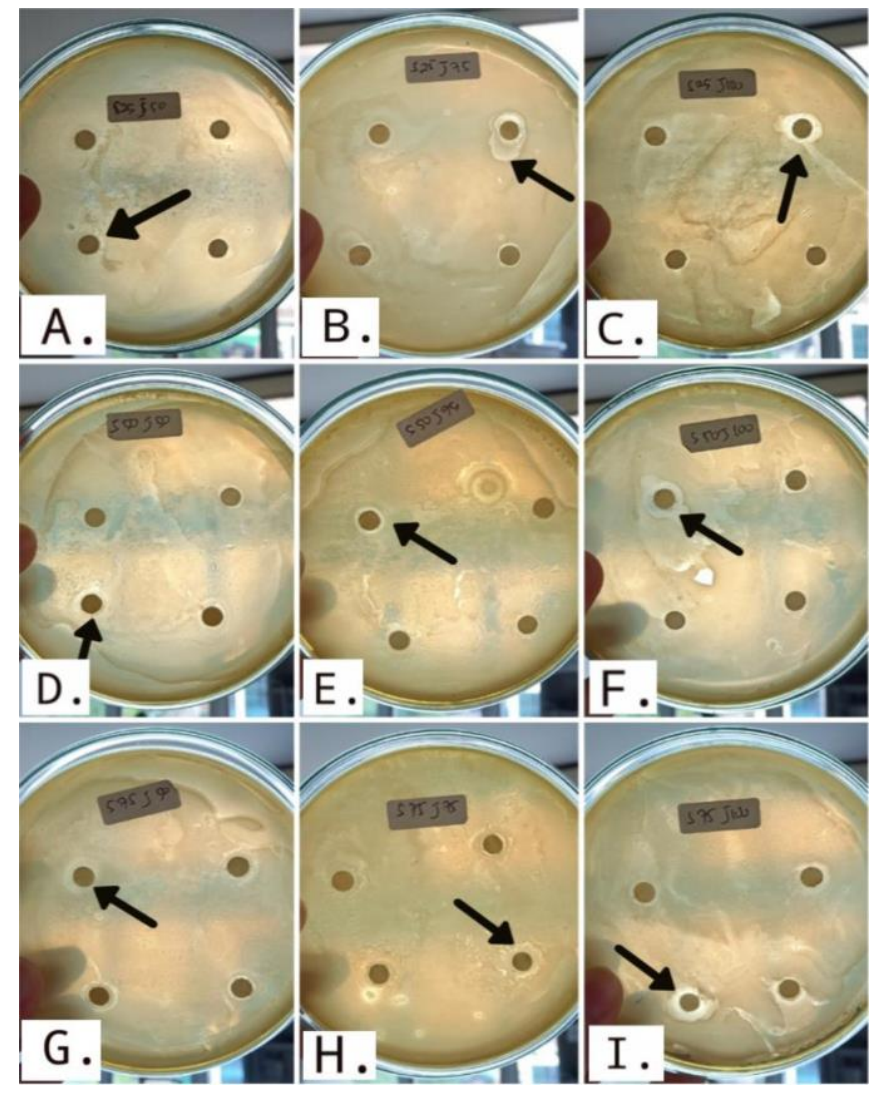

Staphylococcus aureus

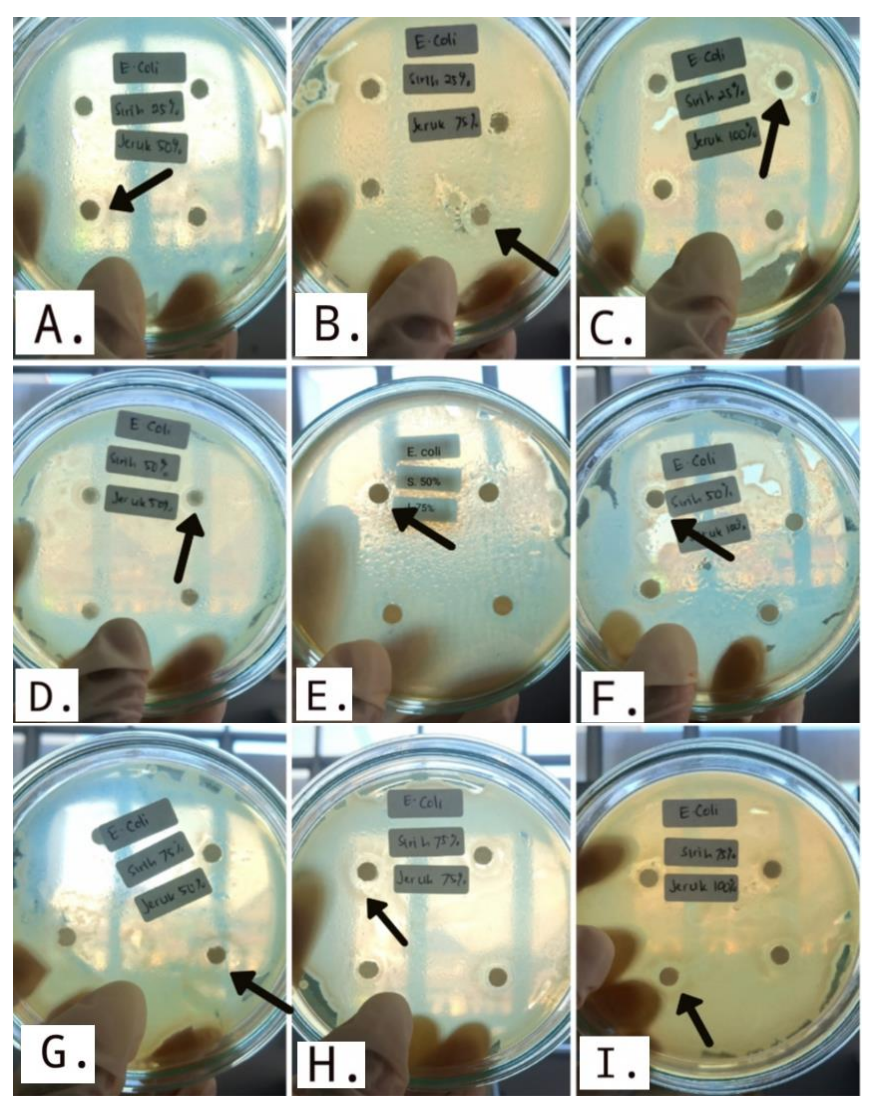

Escherichia coli

Figure 1. Inhibition zone in Staphylococcus aureus (left) and Escherichia coli (right) bacteria in 9 treatmnents; A = P2 (25\% Betel Leaf Extract and 50\% Lime Extract); B = P3 (25\% Betel Leaf Extract and 75\% Lime Extract); C = P4 (25\% Betel Leaf Extract and 100\% Lime Extract); D = P5 (50\% Betel Leaf Extract and 50\% Lime Extract); E = P6 (50\% Betel Leaf Extract and 75\% Lime Extract); F = P7 (50\% Betel Leaf Extract and 100\% Lime Extract); G = P8 (75\% Betel Leaf Extract and 50\% Lime Extract); H = P9 (75\% Betel Leaf Extract and 75\% Lime Extract); and I = P10 (75\% Betel Leaf Extract and 100\% Lime Extract)

Escherichia coli is a gram-negative bacteria under conditions of the normal ordinary was found in the intestines. The bacteria do not harm the small intestine and rarely cause health problems (Gomes et al. 2016). E. coli are divided into five groups according to the level of pathogenic gastrointestinal. The five groups are: (i) Enteropathogenic E. coli (EPEC); (ii) Enterotoxigenic E. coli (ETEC); (iii) Enteroinvasive E. coli (EIEC); (iv) Enteroaggregative $E$. coli (EAEC); and (v) Enterohemorrhagic E. coli (EHEC) (Meng et al. 2012).

The higher the concentration of green betel increase inhibitory power on the growth of $S$. aureus and E. coli. One example is a study conducted by Fahdi (2018) who reported that high concentrations such as green betel leaf extract inhibit the growth of $S$. aureus and $E$. coli. Betel leaf extract has an effect on the growth of S. aureus and $E$. coli, which is indicated by the presence of clear zones formed on the media. Extracts of green betel not only effective against the growth of bacteria $S$. aureus and $E$. coli. Other studies have discussed its effectiveness against other bacteria, including Acnevulgaris (Carolia and Noventi 2016). Betel leaf is an active therapeutic herbal leaf that acts in microbial infections, especially in the oral cavity (Pradhan et al. 2013). Extract of green betel showed inhibitory effect on the growth of colony diameter (Maimunah and Pandala 2019). Piper betle possed promising antibacterial potential with inhibitory activity against at least one out of the six bacteria namely, E. coli (ATCC 25922), S. aureus (ATCC 25923), Pseudomonas aeruginosa (ATCC 27853), Propionibacterium acnes (ATCC 6919), Staphylococcus epidermidis (ATCC 12228), and Streptococcus pyrogenes (ATCC 19615). It has been stated that the bacteriostatic effect is shown by their high flavonoid contents (Taukoorah et al. 2016; Elfrida et al. 2020). Lime (Citrus aurantifolia) also has an essential oil to inhibit the growth of E. coli, Pseudomonas aeruginosa, S. aureus, and Aspergillus niger. The essential oil was isolated from the peels (Edogbanya et al. 2019) and also found in its leaves (Al-Aamri et al. 2018; Lemes et al. 2018). The peels are also effective against $E$. coli (Shakya et al. 2019). The peel extract which can inhibit the growth of $S$. aureus in the sensitive category is $80 \%$ (Ekawati et al. 2019). The essential oil content in citrus shows a reducing effect on the growth rate of $S$. aureus and $E$. coli. The content of essential oils causes lysis of the cell walls, 
intracellular leakage and can cause bacterial death ( $\mathrm{Li}$ et al. 2019; Thielmanand et al. 2019).

There are several factors that cause differences in the effectiveness of natural hand sanitizers. Among them are the nutritional factors of betel leaf extract and lime extract which have not been tested directly. Lime is known to have flavonoids that are found in several parts and can be used as antioxidants and antibacterials (Lin et al. 2019). While in Piper betle, ethanolic extracts showed most effective result as an antibacterial component (Sarma et al. 2018)

Based on the results of the study, it can be concluded that combination of green betle leaves extract and citrus lime extract is able to inhibit the growth of $S$. aureus and $E$. coli bacteria. The combination of betel leaves and lime extract is one of the alternatives of making hand sanitizer experience that is easier and cheaper.

\section{ACKNOWLEDGEMENTS}

We would like to thank all laboratory staff and assistants of the Faculty of Teacher Training and Educational Sciences, IAIN Syekh Nurjati Cirebon, Indonesia who have given us the facility for research.

\section{REFERENCES}

Al-Aamri MS, Al-Abousi,NM, Al-Jabri SS, Alam T, Khan, SA. 2018. Chemical composition and in-vitro antioxidant and antimicrobial activity of the essential oil of Citrus aurantifolia L. leaves grown in Eastern Oman. J Taibah Univ Med Sci 13 (2): 108-112. DOI: 10.1016/j.jtumed.2017.12.002.

Bustanussalam B, Apriasi D, Suhardi E, Jaenudin D. 2015. Antibacterial effectiveness of betel leaf extract (Piper betle Linn) against Staphylococcus aureus ATCC 25923. Fitofarmaka Pharmaceut Sci J 5 (2): 58-64. DOI: 10.33751/jfv5i2.409. [Indonesian]

Carolia N, Noventi W. 2016. The potential of green betel leaf extract (Piper betle L) as an alternative therapy for Acne vulgaris. Majority 5 Journal (1): 140-145. [Indonesian]

DeLeo FR, Otto M, Kreiswirth BN, Chambers HF 2010. Communityassociated meticillin-resistant Staphylococcus aureus. Lancet 375 (9725): 1557-1568. DOI: 10.1016/S0140-6736(09)61999-1.

Edogbanya P, Suleiman M, Olorunmola J, Oijagbe IJ. 2019. Comparative study on the antimicrobial effects of essential oils from peels of three citrus fruits. J Biol Med 4: 49-54. DOI 10.15406/mojbm.2019.04.00113.

Ekawati ER, Pradana MS, Darmanto WIN. 2019. Lime (Citrus aurantifolia) peel as natural antibacteria for wound skin infection caused by Staphylococcus aureus. Int J Pharm Res 11: 363-366. DOI: 10.31838/ijpr/2019.11.01.042.

Elfrida E, Junaida E, Ariska RN, Jayanthi S. 2020. Effect of Piper betle Linn extract on the growth of Staphylococcus aureus ATCC 25923. Budapest Int Res Critics Inst (BIRCI-J) Human Soc Sci 3(4): 3028 3034.

Fahdi F. 2018. Antibacterial activity test of betel leaf extract (Piper betle L.) against the growth of Staphylococcus aureus and Escherichia coli bacteria. J Publ Health Commun 5 (2): 58-64. DOI: 10.26874/kjif.v5i2.129.
Gomes TA, Elias WP, Scaletsky IC, Guth BE, Rodrigues JF, Piazza RM, Ferreira LC, Martinez MB. 2016. Diarrheagenic Escherichia coli. Braz J Microbiol 47 Suppl 1: 3-30. DOI: 10.1016/j.bjm.2016.10.015.

Jing JLJ, Pei Yi T, Bose RJ, McCarthy JR, Tharmalingam N, Madheswaran T. 2020. Hand sanitizers: A review on formulation aspects, adverse effects, and regulations. Intl J Environ Res Publ Health 17 (9): 3326. DOI: 10.3390/ijerph17093326.

Kursia S, Lebang JS, Nursamsiar N. 2016. Antibacterial activity test of green betel leaf ethyl acetate extract (Piper betle L.) against Staphylococcus epidermidis bacteria. Indon J Pharm Sci Technol 3 (2): 72-77. [Indonesian]

Lauma SW. 2015. Test the effectiveness of lime juice extract (Citrus aurantifolia s) against the growth of Staphylococcus aureus bacteria in vitro. Pharmacon 4(4): 9-15. [Indonesian]

Lemes RS, Alves CC, Estevam EB, Santiago MB, Martins CH, Santos TC, Crotti AE, Miranda ML. 2018. Chemical composition and antibacterial activity of essential oils from Citrus aurantifolia leaves and fruit peel against oral pathogenic bacteria. An Acad Bras Cienc 90 (2): 1285-1292. DOI: 10.1590/0001-3765201820170847.

Li ZH, Cai M, Liu YS, Sun PL, Luo SL. 2019. Antibacterial activity and mechanisms of essential oil from Citrus medica L. var. sarcodactylis. Molecules 24 (8): 1577-1586. DOI: 10.3390/molecules24081577.

Lin LY, Chuang CH, Chen HS, Yang KM. 2019. Lime (Citrus aurantifolia (Christm.) Swingle) essential oils: Volatile compounds, antioxidant capacity, and hypolipidemic effect. Foods 8: 398-408. DOI: 10.3390/foods8090398.

Maimunah A, Pandala C. 2019. The effectiveness of kenikir and betel leaves extract as bio fungicide to the causes of anthracnose disease (Colletotrichum capsici) on chili plants (Capsicum annum L.) with In vitro. Budapest Int Res Exact Sci (BirEx) J 2: 29-36. DOI: 10.33258/birexv2i1.221

Meng J, LeJeune JT, Zhao T, Doyle MP 2012. Enterohemorrhagic Escherichia coli. In: Doyle MP, Buchanan RL (eds.). Food Microbiology: Fundamentals and Frontiers, 4th ed., ASM Press, Washington, DC. DOI: 10.1128/9781555818463.ch12.

Pradhan D, Suri KA, Pradhan DK, Biswasroy P. 2013. Golden heart of the nature: Piper betle L. J Pharm Phytochem 1 (6):147-167.

Prastiwi SS, Ferry F. 2017. Review of the content and pharmacological activity of lime (Citrus aurantifolia S.). Farmaka J 15 (2): 1-8. [Indonesian]

Puspita W, Hairunnisa PDA. 2020. In vitro antibacterial activity of lime fruit juice (Citrus aurentifolia) on Staphylococcus aureus bacteria. Jurnal Ilmiah Farmako Bahari 11 (1): 38-45. [Indonesian]

Sarma C, Rasane P, Kaur S, Singh J, Singh J, Gat Y, Garba U, Kaur, D Dhawan K. 2018. Antioxidant and antimicrobial potential of selected varieties of Piper betle L. (Betel leaf). An Acad Bras Cienc 90 (4): 3871-3878. DOI: 10.1590/0001-3765201820180285.

Sarwono B. 2001. Efficacy and Benefits of Lime. Agromedia Pustaka, Depok. [Indonesian]

Shakya A, Luitel B, Kumari P, Devkota R, Dahal PR, Chaudhary R. 2019. Comparative study of antibacterial activity of juice and peel extract of citrus fruits. Tribhuvan Univ J Microbiol 6: 82-88. DOI: 10.3126/tujm.v6i0.26589.

Taukoorah U, Lall N, Mahomoodally F. 2016. Piper betle L.(betel quid) shows bacteriostatic, additive, and synergistic antimicrobial action when combined with conventional antibiotics. South Afr J Bot 105: 133-140. DOI: 10.1016/j.sajb.2016.01.006.

Thielmann J, Muranyi P, Kazman P. 2019. Screening essential oils for their antimicrobial activities against the foodborne pathogenic bacteria Escherichia coli and Staphylococcus aureus. Heliyon 5 (6): e01860. DOI: 10.1016/j.heliyon.2019.e01860.

Tong SY, Davis JS, Eichenberger E, Holland TL, Fowler VG. 2015. Staphylococcus aureus infections: Epidemiology, pathophysiology, clinical manifestations, and management. Clin Microbiol Rev 28 (3): 603-661. DOI: 10.1128/CMR.00134-14. 